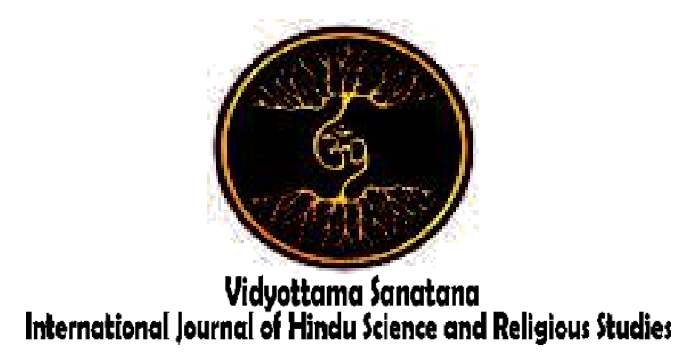

Vol. 2 No. 2 October 2018

\title{
Character Education Value in the Ngendar Tradition in Piodalan at Penataran Agung Temple
}

\author{
By: \\ Kadek Widiastuti ${ }^{1}$, Heny Perbowosari ${ }^{2}$ \\ ${ }^{12}$ Institut Hindu Dharma Negeri Denpasar \\ E-mail : ${ }^{2}$ henysari74@gmail.com
}

\begin{abstract}
The ways to realize the generation which has a character can be apply in the social education through culture values, social ideology and religions, there are in Ngendar' traditions that was doing by the children's in Banjar Sekarmukti, Pangsan Village, Petang District, Badung regency. The purpose of this research to analyze the character values from Ngendar tradition. The types of this research are qualitative which ethnographic approach is. These location of this research in Puseh Pungit temple in Penataran Agung areal, Banjar Sekarmukti, Pangsan Village. Researcher using purposive sampling technique to determine information, collecting the data's using observation, interviews, literature studies and documentation. The descriptive qualitative technique' that are use to data analyses. The result of this research to show; first is process of Ngendar as heritage that celebrated in six months as an expression about grateful to the God (Ida Sang Hyang Widi Wasa). The reasons why these traditions' always celebrated by the children's are affected from holiness, customs and cultures. Second, Ngendar on the naming the characters which is as understanding character children's with their religion that are affected by two things, the naming about religion behavior with way reprimand and appreciation through their confidence (Sradha) and Karma Phala Sradha. Next function is to grow their awareness. There are awareness that growed on their souls is to practice Ngendar traditions', as awareness conscience, have an empathy and love the kind. The third function is in Ngendar tradition was happened on the actualizations those appearance of the habits to doing kindness, actualizations appearances on their social activities and actualization attitude. The third result from the implication education character value were has in Ngendar tradition that do by the children's is implication religious value, implication honest value, implication discipline value, implication awareness environment value and implication the responsibilities.
\end{abstract}

Keywords: Character Value, Ngendar Tradition 


\section{Introduction}

Education has become part of human life to direct the attitudes and behaviors of human beings who have humanitarian qualities. Along with the development of science and technology in this era and also various steps are taken to advance education in Indonesia, however, deviant behavior is also increasingly haunting human behavior, especially after children and adult. The deviant behavior that often happens today becomes a problem that must be resolved soon.

Based on data's from the National Narcotics Agency (BNN) of Bali Province, of 974 people following drug abuse rehabilitation, in 2016, 21 were students. Viewed from the age range, 0-15 years of rehabilitation cases as many as six (6) people and vulnerable aged 16-20 years there are 70 cases. And for the dominant areas of drug abuse, Badung regency reaches ten (10) cases with eleven (11) suspects (Bali BNN Statistics Year 2016).

This phenomenon shows, there are still many negative impacts received by children due to the influence of the environment, and the Badung regency, with a crowded society becomes a threat in the circulation of drugs. Various phenomena involving these children are greatly influenced by the environment where children live. One effort to minimize the occurrence of deviant behavior is to realize a generation that has a sublime character that can be poured in character education. Character education is not only the responsibility of the school as a formal educational institution, but all education spheres participate in it, including informal (family) and nonformal (community) education. Character education efforts that occur in the community through the planting of cultural values, customs and religion, one of the role of public education. This is contained in the tradition of Ngendar conducted by children in Banjar Sekarmukti, Pangsan Village, Petang District, Badung Regency. The value of character education exists in the execution of this tradition which in the activities of the children mutually cooperate to complete the responsibilities given.

\section{Methods}

Research method is defined as a scientific way to get data with a specific purpose and usefulness (Sugiyono, 2014: 5). Research method is a tool to draw conclusions, explain and analyze problems as well as a tool to solve problems in other words is the embodiment of the method of thinking. Assigning appropriate methods in a study is important, because the method concerns about the problem of work to understand the object that the target researchers

The data obtained through research the value of character education in Ngendar tradition at the time of piodalan in Pura Penataran Agung, Banjar sekarmukti, Pangsan Village, Petang District, Badung Regency. Obtaining data both primary data and secondary data through observation methods, interviews, document studies and literature. The technique to determine the informant is to use purposive sampling technique. The data obtained then analyzed by various stages of data reduction, presenting data, verify data and draw conclusions. The presentation of the results of the analysis is presented descriptively qualitative, which is the presentation of the description of words that describe the events naturally in the field.

\section{Result and Discussion}

Ngendar tradition was performed by children have not been returned in Banjar Sekarmukti, Pangsan Village, Petang District, Badung Regency in piodalan in Penataran Agung Temple. There are several factors that make this tradition can only be done by children such as the history that became the mythology of society and related to the sanctity of upakara made in the tradition, the habituation factor and the customary and cultural factors that each age group has a role in the success of piodalan in Penataran Agung Temple. 
Various activities has been done by children and the interaction of children with other groups such as Pemangku and Saya Teruna make Ngendar tradition as a place of character planting for children, including; The cultivation of an understanding of religious behavior, which occurs through reprimands and awards given to children when wronged, and supported by belief in Ida Sang Hyang Widhi (Widhi Sradha) and belief in the law of karma (Karmaphala Sradha) Child against behavior that may be done and vice versa.

Then the second function is the growing awareness of religious behavior, such as the growth of conscience awareness to do good deeds, the growth of empathy (tat twam ation) as well as the growing sense of love for good. Furthermore, some behaviors realized in this teradisi, namely the emergence of a habit when in the holy place, behavior in social activities and ethics in making upakara. Implementation of this sacred tradition encourages the creation of the values of the characters according to what is stated in Kemediknas 2010 about 18 values of character.

Ngendar Tradition conducted by children in Banjar sekarmukti, Pangsan Village, Petang District, Badung Regency at the time of piodalan in Pura Penataran Agung, encourage the creation of some character naiai, such as only religious values, honest, discipline, environmental care and responsibility. This tradition is done by children aged 9 years to 12 years, where the activities undertaken are majejaitan, cooking and metanding. The beliefs that support the sacred activities of the children make the children obedient to obey the existing rules, in carrying out the Ngendar tradition that demands holiness. Upakara offerings in the form of Banten Endar, is one way children to show gratitude and bhakti to Ida Sang Hyang Widhi Wasa.

\section{Conclution}

Based on the results of research on the value of character education in Ngendar tradition it is found that, children have an important role in the implementation of piodalan in Pura Penataran Agung. Various activities performed by children such as making upakara, cooking, to clean the area of the shrine, which makes Ngendar tradition serves to instill the value of character in children. The function is like instilling an understanding of religious behavior, encouraging awareness in religious behavior and the third function is to actualize the act of religion. Various activities and actions carried out by children in the implementation of Ngendar tradition further raises some values of character education such as, religious values, honest values, discipline value, environmental care value and responsibility value. These five values become a habit that shapes the children's behavior while in the susi and provide supplies of children in daily activities that are based on the value of characters that have been embedded in the Ngendar tradition.

\section{References}

Data Statistik BNN Provinsi Bali tahun 2016 Lickona, Thomas. 2012. Educating For Character: Mendidikan Untuk Membentuk Karakter, Bagaiamana Sekolah dapat Mengajarkan Sikap Hormat dan Tanggungjawab. Jakarta: Bumi Aksara.

Lickona, Thomas. 2013. Pendidikan Karakter: Panduan Lengkap Mendidik Siswa Menjadi Pintar dan Baik. Bandung: Nusa Media.

Pudja, G. 1999. Bhagawad Gita (Pancama Veda). Surabaya: Paramita

Sugiyono. 2014. Metode Penelitian Pendidikan Pendekatam Kuantitatif, Kualitatif dan $R \& D$. Bandung. Alfabeta.

Zubaedi. 2011. Desain Pendidikan Karakter: Konsepsi dan Aplikasinya dalam Lembaga Pendidikan. Jakarta: Kencana Prenada Media Grup. 